\title{
Stomach intestinal pylorus sparing surgery (SIPS) with laparoscopic fundoplication (LF): a new approach to gastroesophageal reflux disease (GERD) in the setting of morbid obesity
}

\author{
Hinali Zaveri, Amit Surve, Daniel Cottam, Christina Richards, Walter Medlin, LeGrand Belnap, \\ Samuel Cottam and Austin Cottam
}

\begin{abstract}
The increase in the prevalence of obesity and gastroesophageal reflux disease (GERD) has paralleled one another. Laparoscopic fundoplication (LF) (Nissen or Toupet) is a minimally invasive form of anti-reflux surgery. The duodenal switch is a highly effective weight loss surgery with a proven record of long term weight loss success. However, fundoplication alone does not give satisfactory results when used for GERD in morbidly obese patients. Here we present a novel approach combining stomach intestinal pylorus sparing surgery (SIPS) with LF for morbidly obese patients with GERD. The data from patients who underwent the SIPS procedure along with LF in past year was retrospectively analyzed. The variables collected were age, sex, height, weight, intra-operative and post-operative complications, length of stay, operative time, and estimated blood loss. All revisions were excluded. Descriptive statistics such as mean and standard deviation were used to analyze the data. The total sample size of the study was 5 patients, with a mean age of $59.6 \pm 16.4$ years, a mean weight of $292.1 \pm 73.6 \mathrm{lbs}$., and a mean body mass index (BMI) of $43.4 \pm 6.3$. Weight loss patterns were the same as those without LF. All the 5 patients had resolution or improvement in their GERD symptoms within 6 months. SIPS with LF provides substantial and sustained weight loss and GERD resolution. Long term follow ups and further study on this novel surgical technique is recommended.
\end{abstract}

Keywords: Duodenal switch, Fundoplication, GERD, Obesity, Weight loss, Reflux

\section{Background}

Morbid obesity is a chronic disease which leads to progressive co-morbidities, socio-economic problems, undesirable quality of life, and earlier death. To date only metabolic/bariatric surgeries have achieved significant weight loss, with the corresponding correction or improvement of co-morbidities, improving quality of life. Duodenal switch (DS) is one of the most efficacious forms of bariatric surgical therapy for the morbidly obese available to the clinician (Hess et al. 2005; Buchwald et al. 2004).

*Correspondence: drdanielcottam@yahoo.com

Bariatric Medicine Institute, 1046 East 100 South, Salt Lake City, UT 84102, USA
Gastroesophageal reflux disease (GERD) is a common comorbidity associated with obesity (Hampel et al. 2005). However, laparoscopic fundoplication (LF) does not give satisfactory results in treatment for GERD in morbidly obese patients since obesity predisposes the patient to high rates of LF failure (Antanavicius et al. 2008; Makris et al. 2009).

We report a novel technique involving both LF and a modification of the DS called SIPS (stomach and intestinal pyloric sparing surgery) which together provide optimal weight loss and optimal anti-reflux characteristics while limiting complications associated with another common weight loss intervention for GERD in the setting of morbid obesity(the laparoscopic gastric bypass [LRYGBP]).

\section{Springer}

(c) 2015 Zaveri et al. This article is distributed under the terms of the Creative Commons Attribution 4.0 International License (http://creativecommons.org/licenses/by/4.0/), which permits unrestricted use, distribution, and reproduction in any medium, provided you give appropriate credit to the original author(s) and the source, provide a link to the Creative Commons license, and indicate if changes were made. 


\section{Method}

This is a retrospective analysis of the initial experience from a single surgeon at single institution. The primary objective of this study was to evaluate the SIPS procedure along with LF in terms of weight loss, operative complications, and GERD resolution.

Each patient had a thorough work up for morbid obesity and GERD. All the patients were experiencing GERD symptoms before surgery, and underwent esophagogastroduodenoscopy (EGD) and a transnasal endoscopy (TNE) to assess GERD symptoms and erosive esophagitis (EE). Two patients had a Bravo $\mathrm{pH}$ study and manometry to asses for esophageal dysmotility and to confirm the diagnosis of GERD. The other three patients had giant hiatal hernias on endoscopy with erosive esophagitis. Therefore, we did not do $\mathrm{pH}$ studies or manometry as those diagnostic tests don't work well in the setting of giant hiatal hernias. Additionally, erosive esophagitis is a clear indicator of GERD invalidating the need for $\mathrm{pH}$ studies. All patients were required to provide written informed consent for both the fundoplication and the SIPS procedure before undergoing surgery. All the procedures were performed using a laparoscopic approach. Each patient had a post-operative upper gastro-intestinal (UGI) series prior to leaving the hospital to assess for leaks and obstructions and the adequacy of the wrap. All patients were seen back in clinic for follow up at 1 week, 1 month, 3 months, 6 months, and 1 year. The GERD-HRQL questionnaire was used to assess typical symptoms of GERD.

Descriptive statistics were used to calculate the mean and standard deviation of pre-operative characteristics such as age, weight, height, and BMI. Procedure time was gathered and started with the first incision and ended with the dressing.

Our research was carried out according to our institutions guidelines and the permission was granted to us to assess the patient's data.

\section{Surgical technique}

Each case begins with placement of four trocars and a liver retractor. Next the short gastric vessels are taken down. This facilitates the dissection of the paraesophageal hernia repair. The entire sac is removed using blunt and sharp dissection using an ultrasonixs dissector (Covidien LLC). This dissection is carried superiorly until approximately $5 \mathrm{~cm}$ of intra-abdominal length is achieved. The hernias are all repaired posterior to the esophagus with a two layer running technique with an endostich and 2.0 surgidac sutures. The first layer is a deep layer that starts where the crus meets inferiorly and goes up to the base of the esophagus. Once the esophagus is reached and we check to make sure there is no anterior defect, the suture line is run down back to the starting point and tied to the end of the stitch. This repair is reinforced with a PTFE felt mesh or Pariatex mesh (Covidien Corp.). Then a 40 French Bougie is placed. Depending on the patient, the wrap is created in a fashion described by Toupet or Nissen.

Next a Sleeve Gastrectomy is performed. The lesser sac is entered $4-6 \mathrm{~cm}$ from the pylorus. Then an Endo GIA (Covidien) stapler is fired along the previously placed sizing tube. Once the staple line reaches the prior LF, the staple line deviates laterally attempting to resect as much of the fundus as possible. Blood vessels to the lesser curve are persevered ensuring adequate blood supply.

The next step is to divide the duodenal bulb. This is done by taking down all the gastro-epiploic vessels from the end of the sleeve dissection to past the pylorus. A band passer is then placed towards the liver under the duodenum, and a window is made through the duodenalhepatic ligament. Once the window is created, an Endo GIA (Covidien) stapler is passed around the duodenum and divides the duodenum $3 \mathrm{~cm}$ from the pylorus circumferentially. The distal duodenal stump is then sewn over with absorbable suture.

Next the ileo-cecal valve is located and traced retrograde to $300 \mathrm{~cm}$, and that point is brought up and sewn to the proximal duodenal staple line. The loop limb is sewn to the proximal duodenal stump using 2.0 Polysorb (Covidien). Enterotomies are made in both the limbs and 3.0 Polysorb is used to do another posterior row and anterior row (Fig. 1).

The anastomoses are tested intra-operatively with pressurized air to check for leaks. The resected portion of the stomach is taken out of the abdominal cavity. Antibiotics and deep vein thrombosis (DVT) prophylaxis are used in all patients. The patients are discharged the next day if they do not exhibit nausea, vomiting or any other discomfort.

\section{Classification of erosive esophagitis}

All patients receive preoperative endoscopic evaluation. The diagnosis and classification is based on Los Angeles (LA) classification (Lundell et al. 1999). Table 1 explains the classification.

\section{Grading of the gastroesophageal valve}

Endoscopic grading of the gastroesophageal valve provides useful information about the reflux status (Öberg et al. 1999). To evaluate the same, we use the Hill Valve Grading Scheme (Hill et al. 1996). The geometry of the gastroesophageal valve is assessed with the endoscope in the retroflexed position. The presence and appearance of the gastroesophageal flap valve is graded as I through IV. 


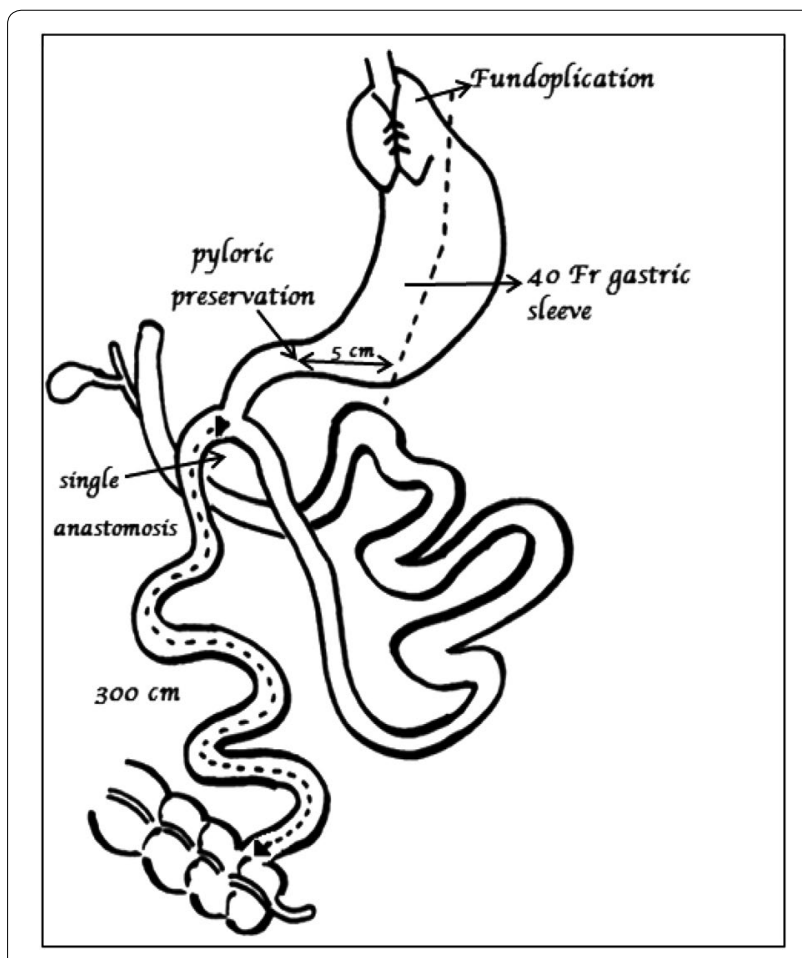

Fig. 1 Diagrammatic representation of SIPS with Nissen Fundoplication

Grade I gastroesophageal valve-defined by the presence of a prominent fold of tissue closely approximated to the shaft of the endoscope and extending 3-4 cm along the lesser curve at the entrance of the esophagus into the stomach.

Grade II gastroesophageal valve-The fold of tissue is less prominent, and there are occasional periods of opening and rapid closing around the endoscope with respiration.

Grade III gastroesophageal valve-There is no prominent fold at the entrance of the esophagus into the stomach, and the endoscope is not tightly gripped by the tissues.

\section{Table 1 Los Angeles classification for erosive esophagitis}

\begin{tabular}{|c|c|}
\hline Grade & Definition \\
\hline A & $\begin{array}{l}\geq 1 \text { mucosal breaks } \leq 5 \mathrm{~mm} \text { long, none of which extends } \\
\text { between the tops of the mucosal folds }\end{array}$ \\
\hline B & $\begin{array}{l}\geq 1 \text { mucosal breaks }>5 \mathrm{~mm} \text { long, none of which extends } \\
\text { between the tops of mucosal folds }\end{array}$ \\
\hline C & $\begin{array}{l}\text { Mucosal breaks that extend between the tops of } \geq 2 \text { mucosal } \\
\text { folds, but which involve }<75 \% \text { of the esophageal circumfer- } \\
\text { ence }\end{array}$ \\
\hline D & $\begin{array}{l}\text { Mucosal breaks which involve } \geq 75 \% \text { of the esophageal } \\
\text { circumference }\end{array}$ \\
\hline
\end{tabular}

Grade IV gastroesophageal valve-The patient has a large hiatal hernia and essentially no fold where the lumen of the esophagus is gaping open, allowing the squamous epithelium to be viewed from below.

\section{Measurement of reflux symptoms}

The GERD-Health Related Quality of Life Questionnaire (GERD-HRQL) is a self-assessed, reliable, valid, responsive, and practical measure of symptom severity in patients with GERD (Velanovich et al. 1996; Velanovich 2007). It's a 10-item questionnaire with an assessment of overall satisfaction. Items are scored on a 6 point scale $(0-5)$, addressing domains like heartburn (Items 1-6), dysphagia (item 7), odynophagia (item 8), meteorism (item 9), effect of medications (item 10), and satisfaction level. But no extra-esophageal symptoms are included. It is evaluated post operatively at 6 months and 1 year. The heartburn score is calculated by summing the individual score to questions $1-6$, with score of 30 being the worst heartburn and score of 0 being no heartburn. Any score of $\leq 12$ with each individual question not exceeding 2 indicates heartburn elimination. The total score is calculated by summing the individual scores to questions $1-10$, with greatest possible score of 50 (worst symptoms) and lowest possible score of 0 (no symptoms) (Hunter et al. 1996).

\section{Results}

We analyzed a total of 5 patients aged between 18-85 years. The pre-operative characteristics are shown in Table 2. The mean operative time overall was $115 \mathrm{~min}$. The mean estimated blood loss was $35 \mathrm{cc}$. The mean post-operative hospitalization stay was $2.4 \pm 1.14$ days. Two patients $(40 \%)$ had perioperative complications. One patient had an ileus, while the other had low oxygen saturation on day 2. However, both the complications were mild and patients recovered uneventfully. The first patient returned within 30 days of the surgery with nausea, vomiting, diarrhea, and clostridium difficile colitis. Only one (20\%) reported dysphagia (Post op $>30$ days). Table 3 highlights operative outcomes.

Table 2 Preoperative characteristics

\begin{tabular}{|c|c|}
\hline No. of patients & 5 \\
\hline Age $\left(\right.$ years) ${ }^{a}$ & $59.6 \pm 16.4$ \\
\hline Weight (lbs. $)^{\mathrm{a}}$ & $292.1 \pm 73.6$ \\
\hline Height (in) ${ }^{\mathrm{a}}$ & $68.3 \pm 4.2$ \\
\hline $\mathrm{BMI}^{\mathrm{a}}$ & $43.4 \pm 6.3$ \\
\hline Male & 3 \\
\hline Female & 2 \\
\hline Ideal Body Weight (Ibs.) ${ }^{a}$ & $147.5 \pm 26.1$ \\
\hline Excess body Weight (lbs.) ${ }^{a}$ & $144.6 \pm 51.5$ \\
\hline
\end{tabular}


Table 3 Post-op complications

\begin{tabular}{ll}
\hline lleus & 1 \\
Low oxygen saturation & 1 \\
Nausea with Diarrhea (Clostridium Difficile Colitis) & 1 \\
Dysphagia requiring intervention & 1 \\
Readmission $<30$ days & 1 \\
\hline
\end{tabular}

\section{Weight loss analysis}

Each patient's weight loss mirrored our larger group of SIPS patient. Refer to Table 4 for complete analysis.

\section{GERD analysis}

Refer to Table 5 for complete pre-operative and postoperative GERD analysis.

Table 6 summarizes the post-operative GERD-HRQL scale.

\section{Discussion}

The increasing prevalence of obesity worldwide has coincided with an increasing prevalence of GERD (Hampel et al. 2005). Morbid obesity is a key risk factor for GERD partly because obesity increases the intra-abdominal pressure, generating the forces necessary to cause reflux (Hampel et al. 2005; Barak et al. 2002; Groot et al. 2009). Obese patients may have an increased risk for hiatal hernia, which has a role in initiating and promoting GERD (Kahrilas 1999). Although LF is not the only treatment modality for intractable GERD, it is the preferred method for most surgeons.

Several studies have suggested that Roux-en-Y gastric bypass is a more effective operation for GERD than Nissen fundoplication in the morbidly obese GERD patients (Braghetto et al. 2012; Varela et al. 2009). While proponents are correct to argue that LRYGBP does eliminate GERD in most patients and it is a successful weight loss

Table 4 Weight loss analysis

\begin{tabular}{llllc}
\hline Months & $<\mathbf{3}$ months $(\mathbf{n}=\mathbf{5})$ & $\mathbf{3 - 6}$ months $(\mathbf{n}=\mathbf{5})$ & $\mathbf{7 - 1 2}$ months $(\mathbf{n}=\mathbf{2})$ & $>\mathbf{1 2}$ months $(\mathbf{n}=\mathbf{2})$ \\
\hline Total body weight loss (lbs.) & $42.1 \pm 11.6$ & $69.9 \pm 30.1$ & $86.5 \pm 14.1$ & $98.9 \pm 13.1$ \\
Total body weight loss (\%)a & $14.5 \pm 2.3$ & $23.4 \pm 5.2$ & $33.1 \pm 0.2$ & $38 \pm 1.5$ \\
Excess weight loss (\%)a & $29.9 \pm 5.8$ & $47.9 \pm 8$ & $73.5 \pm 5.3$ & $84.2 \pm 3.4$ \\
BMl reduction (kg/m2)a & $6.3 \pm 1.2$ & $10.3 \pm 3.5$ & $13.2 \pm 0.1$ & $15.1 \pm 0.4$ \\
Excess BMl loss (\%)a & $35.8 \pm 9.1$ & $56.8 \pm 11.5$ & $89.1 \pm 2.7$ & $102.2 \pm 6.4$ \\
\hline
\end{tabular}

${ }^{a}$ Values are expressed as mean \pm SD

Table 5 GERD analysis

\begin{tabular}{|c|c|c|c|c|c|c|}
\hline \multirow[t]{2}{*}{ Subjects } & \multicolumn{3}{|c|}{ Pre-operative TNE + EGD } & \multirow[t]{2}{*}{ Surgery } & \multirow{2}{*}{$\begin{array}{l}\text { Post-operative } \\
\text { GERD-HRQL } \\
\text { Scale }\end{array}$} & \multirow[t]{2}{*}{ Extra notes } \\
\hline & $\begin{array}{l}\text { LA Classifi- } \\
\text { cation }\end{array}$ & $\begin{array}{l}\text { Grading of GE } \\
\text { Valve }\end{array}$ & Hernias & & & \\
\hline 1 & $\mathrm{D}$ & IV & $\begin{array}{l}5 \mathrm{~cm} \text { Sliding Hiatal } \\
\text { Hernia }\end{array}$ & $\begin{array}{l}\text { SIPS + HHR with } \\
\text { Mesh + NF }\end{array}$ & 0 & $\begin{array}{l}\text { Pre-operative Bravo PH study was posi- } \\
\text { tive for abnormal distal esophageal } \\
\text { acid exposure } \\
\text { DeMeester score-105.5 }\end{array}$ \\
\hline 2 & A & IV & $\begin{array}{l}8 \mathrm{~cm} \text { Sliding Hiatal } \\
\text { Hernia }\end{array}$ & $\mathrm{SIPS}+\mathrm{NF}$ & 19 & $\begin{array}{l}\text { Patient had history of esophageal dys- } \\
\text { motility syndrome } \\
\text { Post-operative manometry at } 3 \text { months } \\
\text { showed poor esophageal dysmotility } \\
\text { which was contributed to past history } \\
\text { of motility disorder }\end{array}$ \\
\hline 3 & C & IV & $\begin{array}{l}5 \mathrm{~cm} \text { Sliding Hiatal } \\
\text { Hernia }\end{array}$ & $\begin{array}{l}\text { SIPS + HHR with } \\
\text { Mesh + NF }\end{array}$ & 1 & $\begin{array}{l}\text { Pre-operative bravo pH study was posi- } \\
\text { tive for abnormal distal esophageal } \\
\text { acid exposure } \\
\text { DeMeester score was } 23.6\end{array}$ \\
\hline 4 & $\mathrm{D}$ & IV & $\begin{array}{l}6 \mathrm{~cm} \text { Sliding +huge } \\
\text { paraesophageal } \\
\text { hernia }\end{array}$ & $\begin{array}{l}\text { SIPS + Paraesophageal } \\
\text { Hernia Repair with } \\
\text { Mesh + complete } \\
\text { fundoplication }\end{array}$ & 9 & \\
\hline 5 & B & $\|$ & $\begin{array}{l}\text { Huge paraesophageal } \\
\text { Hernia }\end{array}$ & $\begin{array}{l}\text { SIPS + Paraesophageal } \\
\text { hernia repair with } \\
\text { mesh + NF }\end{array}$ & 2 & $\begin{array}{l}\text { Upper GI series at } 6 \text { months showed } \\
\text { intake Nissan with no reflux }\end{array}$ \\
\hline
\end{tabular}


Table 6 Post-operative GERD-HRQL SCALE

\begin{tabular}{llllllll}
\hline Patients no. & $\begin{array}{l}\text { Heartburn } \\
\text { Score (Q 1-6) }\end{array}$ & Dysphagia & Odynophagia & Meteorism & $\begin{array}{l}\text { Effect of } \\
\text { medications }\end{array}$ & $\begin{array}{l}\text { Total } \\
\text { score }\end{array}$ & $\begin{array}{l}\text { Satisfaction } \\
\text { level }\end{array}$ \\
\hline 1 & 0 & 0 & 0 & 0 & 0 & 0 & Satisfied \\
2 & 10 & 2 & 2 & 5 & 0 & 19 & Satisfied \\
3 & 0 & 0 & 0 & 1 & 0 & 3 & Satisfied \\
4 & 6 & 0 & 0 & 3 & 0 & 2 & Satisfied \\
5 & 0 & 0 & 0 & 2 & 0 & 6.2 & Satisfied \\
Mean & 3.2 & 0.4 & 0.4 & & & & Satisfied \\
\hline
\end{tabular}

operation, the gastric bypass surgery yields significant long term complications associated with the creation of the Roux limb such as ulcers, strictures, intussusceptions, dysfunctional Roux limb syndrome, internal hernias, slippage of the gastric pouch, and dumping syndrome. The SIPS with LF is not subject to these side effects (Iannelli et al. 2006; Ledoux et al. 2014; Gasteyger et al. 2008; Zellmer et al. 2014). Because of these side effects, Gastric Bypass may not be an ideal operation for all morbidly obese GERD patients especially for patients who require long term NSAID therapy which is associated with bleeding ulcers postoperatively.

Laparoscopic Sleeve Gastrectomy (SG) is one of the most commonly used Bariatric Surgeries. However, SG alone may cause or worsen GERD, as mentioned in the literature (Santoro et al. 2014; Tai et al. 2013; Peterson et al. 2012). Obesity itself also worsens GERD symptoms and causes fundoplication to fail. To achieve adequate weight loss and adequate GERD control in this patient population, we proposed combining two procedures that already provide good disease treatment for both disease processes present.

SIPS is a new technique that is a slight modification of the SADI (Single Anastomosis Duodenal-Ileal bypass) (Sanchz-Pernaute et al. 2010). SIPS differs in that a smaller bougie is utilized, and intestinal length $(3 \mathrm{~m})$ is kept longer. The longer length along with the ileo-cecal valve helps reduce short bowel syndrome. The preservation of the pylorus provides control of solid emptying reducing the chances of dumping syndrome and assisting in maintaining a physiologic based rate of gastric emptying.

However the question that remains is whether this information is of importance to practicing bariatric surgeons and Gasto-surgeons for treating GERD in morbidly obese patients or whether another type of modification is necessary? This was answered recently by Khazzaka and Sarkis (2013) who reported fundoplication with gastric plication in 16 patients. Excess weight loss at 1 year was $10 \mathrm{kgs}$ with resolution of GERD in all 16 patients. Thereafter, surgeons from Taiwan published a paper on Nissen fundoplication with Gastric Plication (greater curvature side plication) in 25 patients with the excess weight loss of $24.6 \mathrm{kgs}$ at 12 months (Lee et al. 2014). However $8 \%$ of their patients had a major complication post operatively. 21 patients out of 25 had improvement with their GERD symptoms. With our technique we observed that our excess weight loss between 3 and 6 months was $69.980 \mathrm{lbs}(31.81 \mathrm{kgs})$ and between 6 and 12 months, it was $86.50 \mathrm{lbs}(39.32 \mathrm{kgs})$ which is more than both the studies with gastric plication.

Indeed a patient losing weight helps improve GERD, but there are some other theoretical explanations for this improvement that can occur before weight loss (Peterson et al. 2012). By performing the SG as a first procedure of SIPS, we remove most oxyntic cells which reduces acid production. (Although it might be obvious, it has never been properly proved.) Even the faster rate of gastric emptying for liquids that is observed with sleeve helps in preventing and treating GERD. Additionally, we have data about the effect of LF on transient LES relaxations (TLESRs). Both partial (Lindeboom et al. 2001) and Nissen Fundoplication (Staathof et al. 2001) reduces the occurrences of TLESRs. Thus combining both the procedures, SIPS with LF, can be a feasible option for the treatment of GERD in morbidly obese patients.

The advantage of this novel technique as the treatment for both obesity and GERD is that the addition of malabsorption with the sleeve and the intestinal bypass make its weight loss more reliable than a sleeve alone, and this compensates for the larger volumes involved in making the LF.

This technique has not been previously discussed. All patients who underwent this combined procedure absolutely did not want a gastric bypass because of its side effects and two were on chronic NSAID therapy. This approach, SIPS with LF, allowed the patients to preserve the efficacy of the LF while maintaining the greater weight loss seen with SIPS (Hess et al. 2005; Buchwald et al. 2004). 
The GERD-HRQL used here, has the advantage over standard health status instruments for GERD including simplicity for patients, high compliance rates, and the ease of understanding by physicians (Velanovich et al. 1996). Among the observed results of the GERD-HRQL questionnaire, questions 1-6 were related to heartburn, a typical symptom that affects patient's quality of life. In this study, all our patients had a heartburn score of less than 12 with mean score of 3.2, which exhibits the elimination of their symptoms. Items 7-9 referred to symptoms of dysphagia, odynophagia, and meteorism considered side effects of the procedure. In this study these items were the main reason in raising the final score. However these symptoms are well tolerated by the patients and show improvement over time after the operation (Balci and Turkcapar 2007; Hamdy et al. 2008). Item 10 was about the use of medication, and all of our patient reported 0 (no symptoms) to this question, revealing low or no need of medication and low impact on their quality of life. The last question of GERD-HRQL assessed the patient's perception about their current health status into 3 levels of satisfaction. It was noted that all of our patients marked satisfied and were between 6 and 12 months after the operation. It's also worth mentioning that our mean total score was 6.2, with more than half of the patients having a total score below 5. Lower GERD-HRQL total scores indicated good quality of life, suggesting that surgical treatment was effective. This modality is better than drug therapy when considering quality of life and patient satisfaction.

There are some limitations in this study. First is the small case number. This study is not meant to provide definitive superiority to LF or LRYGBP alone in the setting of obesity but as a possibility in patients who both LF and LRYGBP are not options for various reasons. Consequently predicting its widespread applicability to all bariatric patients with reflux is premature and awaits larger trials. Secondly, we could not evaluate endoscopy or $\mathrm{pH}$ testing post-operatively in our patients, which is fundamental to evaluate the effect of anti-reflux surgery. Though we could get GERD-HRQL questionnaires for all our patients, we could not compare the data pre and post-surgery. However limited, the data does point to good quality of life following this surgery and this small study should be a stimulus to others in different centers to offer this option who have not considered it before.

According to our short-term follow up after SIPS with LF, we clearly demonstrate that it has effective early weight loss and a satisfactory anti-reflux effect.

Some may call this combined procedure experimental. However, our hospital surgical committee felt that since we were combining two known procedures, no IRB was needed. Additionally, the Blue Cross definition of experimental is any procedure where the outcome is unknown and in this case the two procedures outcomes are well known. The fact that we combined them doesn't alter the effect of either one as we demonstrated.

\section{Conclusion}

In summary, our early results are encouraging. SIPS with LF, is a novel and technically feasible procedure that combines fundoplication and bariatric surgery that can have good anti-reflux effects and substantial weight loss during the short term follow up. Additional long term follow ups and larger study populations would be required to further evaluate the outcomes of this novel technique to see if it is applicable to all bariatric GERD patients or should be reserved for special circumstances like we presented in this paper.

\section{Authors' contributions}

$D C$ is the main investigator and main surgeon of this research who performed all the surgeries, assisted by the fellow surgeons CR, LB and WM. HZ helped to draft the manuscript. AS reviewed the patient's data and gave the interpretation of the reports. SC and AC provided statistical analysis. All the authors read and approved the final manuscript.

\section{Competing interests}

Daniel Cottam, the corresponding author and investigator of this report has no conflicts of interest or financial ties to disclose. Hinali Zaveri has no conflicts of interest or financial ties to disclose. Amit Surve has no conflicts of interest or financial ties to disclose. Christina Richards has no conflicts of interest or financial ties to disclose. Walter Medlin has no conflicts of interest or financial ties to disclose. LeGrand Belnap has no conflict of interest or financial ties to disclose. Samuel Cottam has no conflicts of interest or financial ties to disclose. Austin Cottam has no conflict of interest or financial ties to disclose.

\section{Statement of human and animal rights}

All procedures performed in studies involving human participants were in accordance with the ethical standards of the institutional and/or national research committee and with the 1964 Helsinki declaration and its later amendments or comparable ethical standards. Since this is a retrospective study: the formal consent is not required for this type of study.

Received: 2 September 2015 Accepted: 5 October 2015

Published online: 13 October 2015

\section{References}

Antanavicius G, Leslie D, Torres-Villalobos G et al (2008) Distal esophageal erosion after laparoscopic adjustable gastric band placement with Nissen Fundoplication takendown. Obes Surg 18:1350-1353

Balci D, Turkcapar AG (2007) Assessment of quality of life after laparoscopic Nissen Fundoplication in patients with gastroesophageal reflux disease. World J Surg 31:116-121

Barak N, Ehrenpreis ED, Harrison JR, Sitrin MD (2002) Gastro-oesophageal disease in obesity: pathophysiology and therapeutic considerations. Obesity Rev 3:9-15

Braghetto I, Korn O, Csendes A, Gutierrez L, Valladares H, Chacon M (2012) Laparoscopic treatment of obese patients with gastrooesophageal reflux disease and Barrett's esophagus: a Prospective Study. Obes Surg 22:764-772

Buchwald $H$, Avidor Y, Braunwald E, Jensen MD, Pories W, Fahrbach K et al (2004) Bariatric surgery: a systemic review and meta-analysis. JAMA 292(14):1724-1737 
Gasteyger C, Suter M, Gaillard RC, Guisti V (2008) Nutritional deficiencies after Roux-en-Y gastric bypass for morbid obesity often cannot be prevented by standard multivitamin supplementation. Am J Clin Nutr 87(5):1128-1133

Groot NL, Burgenhart JS, Van De Meeberg PC, De Vries DR, Smout AJPM, Siersema PD (2009) Systemic review: the effects of conservative and surgical treatment for obesity on gastro-oesophageal reflux disease. Aliment Pharmacol Ther 30:1091-1102

Hamdy E, El-Raouf AA, El-Hemaly M, Salah T, El-Hanafy E, Mostafa M et al (2008) Quality of life and patient satisfaction 3 months and 3 years after laparoscopic Nissen's fundoplication. Saudi J Gastroenterol 14(1):24-27

Hampel H, Abraham NS, El-Serag HB (2005) Meta-analysis: obesity and the Risk for Gastroesophageal Reflux Disease and its complications. Ann Intern Med 143(3):199-211

Hess DS, Hess DW, Oakley RS (2005) The biliopancreatic diversion with the duodenal switch: results beyond 10 years. Obes Surg 15(3):408-416

Hill LD, Kozarek RA, Kraemer SJM et al (1996) The gastroesophageal flap valve: in vitro and in vivo observations. Gastrointest Endosc 44(5):541-547

Hunter JG, Trus TL, Branum GD, Waring JP, Wood WC (1996) A physiologic approach to laparoscopic fundoplication for gastroesophageal reflux disease. Ann Surg 223:673-685

Iannelli A, Facchiano E, Gugenheim J (2006) Internal hernias after laparoscopic Roux-en-Y gastric bypass for morbid obesity. Obes Surg 16(10):1265-1271

Kahrilas PJ (1999) The role of hiatus hernia in GERD. Yale J Biol Med 72:101-111

Khazzaka A, Sarkis R (2013) Fundoplication combined with mediogastric plication. Surg Obes related Dis 9:398-404

Ledoux S, Calabrese D, Bogard C et al (2014) Long term evolution of nutritional deficiencies after gastric bypass: an assessment according to compliance to medical care. Ann Surg 259(6):1104-1110

Lee WJ, Han ML, Ser KH, Tsou JJ, Chen JC, Lin CH (2014) Laparoscopic Nissen fundoplication with Gastric plication as a potential treatment for morbidly obese patients with GED, first experience and results. Obes Surg 24:1447-1452

Lindeboom MA, Ringers J, Straathof JW, van Rijn PJ, Neijenhuis P, Masclee AA (2001) Effect of partial fundoplication on reflux mechanisms. Am J Gastroenterol 96(8):2317-2323
Lundell LR, Dent J, Bennette JR et al (1999) Endoscopic assessment of esophagitis: clinical and functional correlates and further validation of Los Angeles classification. Gut 45(2):172-180

Makris KL, Lee T, Mittal SK (2009) Roux-en-Y reconstruction for failed fundoplication. J Gastrointest Surg 13(12):2226-2232

Öberg S, Peters JH, DeMeester TR et al (1999) Endoscopic grading of gastroesophageal valve in patients with symptoms of Gastroesophageal reflux disease (GERD). Surg Endosc 13:1184-1188

Peterson WV, Meile T, Kuper MA, Zdichavsky M, Konigsrainer A, Schneider JH (2012) Functional importance of laparoscopic sleeve gastrectomy for the lower esophageal sphincter in patients with morbid obesity. Obes Surg 22(3):360-366

Sanchz-Pernaute A, Herrera MA, Perez-Aguirre ME et al (2010) Single Anastomosis duodeno-ileal bypass with sleeve gastrectomy (SADI-S), one to three year follow-up. Obes Surg 20(12):1720-1726

Santoro S, Lacombe A, Gasper de Aquino CG, Malzoni CE (2014) Sleeve gastrectomy with anti-reflux procedure. Einstein (Sao Paulo). 12(3)

Staathof JW, Ringers J, Lamers CB, Masclee AA (2001) Provocation of transient lower esophageal sphincter relaxations by gastric distention with air. Am J Gastroenterol 96(8):2317

Tai CM, Huang CK, Lee YC, Chang CY, Lee CT, Lin JT (2013) Increase in gastroesophageal reflux disease symptoms and erosive esophagitis 1 year after laparoscopic sleeve gastrectomy. Surg Endosc 27:1260-1266

Varela JE, Hinojosa MW, Nguyen NT (2009) Laparoscopic fundoplication compared with laparoscopic gastric bypass in morbidly obese patients with gastrooesophageal reflux disease. Surg Obes Related Dis 5(2):139-143

Velanovich V (2007) The development of the GERD-HRQL symptom severity instrument. Dis Esophagus 20:130-134

Velanovich V, Vallance SR, Gusz JR et al (1996) Quality of life scale for gastroesophageal disease. J Am Coll Surg 183:217-224

Zellmer Jd, Mathiason MA, Kallies KJ, Kothari SN (2014) Is laparoscopic sleeve gastrectomy a lower risk bariatric procedure compared with laparoscopic Roux-en-Y gastric bypass? A meta-analysis. Am J Surg 208(6):903-910

\section{Submit your manuscript to a SpringerOpen ${ }^{\circ}$ journal and benefit from:}

- Convenient online submission

Rigorous peer review

- Immediate publication on acceptance

- Open access: articles freely available online

- High visibility within the field

- Retaining the copyright to your article

Submit your next manuscript at $>$ springeropen.com 